Sri Lanka J. Aquat. Sci. 21 (1) (2016): 27-34

\title{
Farming of Nile tilapia (Oreochromis niloticus) in backyard ponds in Sri Lanka: Culture practices, fish production and profitability
}

\author{
K.B.C. Pushpalatha*, J. Chandrasoma†, H.S.W.A. Liyanage, W.A.J.R. \\ Fernando and J.M. Jayabahu
}

National Aquaculture Development Authority of Sri Lanka, 41/1, New Parliment Road, Pelawatta, Battaramulla, Sri Lanka

\author{
$\dagger$ Present address: 153, Horana Road, Panadura, Sri Lanka \\ * Corresponding author (pushpakbc@ gmail com)
}

\begin{abstract}
Government of Sri Lanka through Ministry of Economic Development implemented an island-wide multi-sector programme during 2011-2014 involving rural households with the objective of enhancing nutrition and also to provide supplementary income and livelihoods. Fish farming in backyard/home garden ponds was one of the components under this programme. This was the second attempt by the government to introduce small- scale pond fish farming in Sri Lanka, and the first attempt made during 1980-1983 was a failure.

A total of 2,109 ponds covering an area of 105.45 ha have been established under the current programme. Information pertaining to culture practices, fish production, financial returns and costs involved in respect of these ponds were collected through administering a questionnaire. The survey covered fish ponds in the districts of Gampaha, Puttalam and Ampara. Nile Tilapia (Oreochrimis niloticus) was the only species used for farming. All-male or mixed sex tilapia are being farmed in these ponds. Considerable variations in stocking densities adapted, inputs, fish production, selling prices of fish, operational costs and profitability was observed among ponds in these districts. Average fish production per culture cycle were 9,192 $\mathrm{kg} / \mathrm{ha}$ (Gampaha), 6,074 kg/ha (Puttalam) and 3,270 kg/ha (Ampara). Tilapia farming in ponds is profitable in all three districts. Profit margins are very attractive in respect of ponds in Gampaha and Puttalam.

Recommendations to ensure sustainability in tilapia farming in ponds and for further expansion of fish farming in ponds with special reference to culture practices, fish production, inputs and role of government are made.
\end{abstract}

Keywords: earthen ponds; economics of aquaculture; Nile tilapia; rural aquaculture 


\section{Introduction}

Farming of fish ponds is an age old practice in many countries of the world particularly in the Asian region. Nevertheless, Sri Lanka has no tradition of fish farming. The Ministry of Fisheries of Sri Lanka made an attempt to introduce small scale pond fish farming during 1980-1983 aiming at popularization of freshwater fish farming. This programme included provision of subsidy in the form of cash grants to meet part of the cost of construction of the ponds and aquaculture demonstrations. Although there had been a keen interest for fish farming under this subsidy scheme and around 1500 pond units were established (Chakrabarty 1983), almost all these ponds were found to be abandoned within few years of their establishment.

Government of Sri Lanka through Ministry of Economic Development implemented an island-wide multi-sector Divi Neguma programme during 20112014 , involving rural households with the objective of enhancing nutrition and also for providing supplementary income and livelihoods. Fish farming in home-garden ponds was one of the components under this programme and National Aquaculture Development Authority of Sri Lanka (NAQDA) of the Ministry of Fisheries and Aquatic Resources Development was responsible for the implementation of this component. Government encouraged people to undertake small-scale fish farming in ponds by providing financial assistance to cover construction cost of ponds. Furthermore, prospective fish farmers were given practical-oriented training in fish farming and they were supported by extension service of NAQDA.

Under this programme, a total of 2,109 ponds covering an area of 105.45 ha has been established island-wide. This paper discusses the culture practices adopted by farmers and examines economic aspects including fish production, related costs and profitability of fish farming in backyard ponds in three districts in Sri Lanka. In addition, recommendations are made for further improvement of fish production and expansion of fish farming in ponds with special reference to culture practices, fish production, inputs and role of government.

\section{Materials and Methods}

Information pertaining to backyard fish ponds established in three districts were collected in December 2014 through administering a questionnaire. Three districts covered under this survey were Gampaha in the Western Province, Puttalam in NorthWestern Province and Ampara in Eastern Province. Total of 90, 113 and 153 ponds units respectively in Gampaha, Puttalam and Ampara districts have been established under backyard pond fish farming programme. Survey data included information with respect of pond size, culture period, species used, stocking density, feeding, fertilization of ponds, harvesting, marketing, capital and operational costs etc. The survey covered 13, 9 and 15 pond fish farmers respectively from Gampaha, Puttalam and Ampara districts. 


\section{Results}

\section{Earthen ponds}

Earthen ponds varying in size from $250-3,975 \mathrm{~m}^{2}$ with a mean size of $1,156 \mathrm{~m}^{2}$ have been used for fish farming by fish farmers covered under the survey. In Ampara, all 15 farmers covered under the survey had only one pond each for fish farming, varying in size from $480-1,250 \mathrm{~m}^{2}$ with a mean size of $673 \mathrm{~m}^{2}$. Around $40 \%$ of the farmers in other two districts operated more than one pond. In Gampaha district, pond size ranged from 250-1,690 $\mathrm{m}^{2}$ with a mean area of $480 \mathrm{~m}^{2}$, while in Puttalam district, fish farmers have constructed larger ponds ranging in size from $550-3,975 \mathrm{~m}^{2}$ (mean size $\left.-2,314 \mathrm{~m}^{2}\right)$.

\section{Fish species, Stocking densities and culture period}

Fish species used for farming in all the ponds is Nile tilapia (Oreochromis niloticus). Sixty six percent of fish farmers in Puttalam district and $84 \%$ fish farmers in Gampaha district have used all-male Nile tilapia for farming in their ponds, while the rest of the farmers in these two districts and all the farmers in Ampara district used mixed-sex Nile tilapia. Average stocking densities adopted varied considerably among districts under consideration; Gampaha $5 / \mathrm{m}^{2}$ (range: $2.5-10 / \mathrm{m}^{2}$ ); Puttalam $2.8 / \mathrm{m}^{2}$ (range: from $2-5 / \mathrm{m}^{2}$ ) and Ampara $1.7 / \mathrm{m}^{2}$ (range: $0.8-3.0 / \mathrm{m}^{2}$ ). Culture period in ponds varied from 5 to 8 months in all three districts.

\section{Feeding and fertilization}

It was observed that a wide variety of low cost feed materials have been used to feed fish in backyard ponds in Gampaha and Puttalam Districts. Feed ingredients used included dried fish pieces and heads, broken rice, coconut poonac, cooked poultry waste, kitchen refuse, date-expired bread from bakeries and kankun (Ipomea aquatica) plants. Some farmers used date-expired shrimp feed, when available. All the farmers in Ampara covered under the survey have used poultry feed available in the market.

Considerable variation was observed in the amount of fertilizer used among ponds in three districts. Mainly cow-dung used as fertilizer to enhance growth of natural food organisms. No fertilization of ponds was observed in Gampaha district. Average rate of application of manure is almost four times higher in Puttalam (0.4 $\mathrm{kg} / \mathrm{m}^{2} /$ culture cycle) than that of Ampara $\left(0.12 \mathrm{~kg} / \mathrm{m}^{2} /\right.$ culture cycle $)$.

\section{Harvesting of fish and Marketing}

Average harvesting size varied among backyard ponds in the three districts. Weights of harvested fish were around $500 \mathrm{~g}$ (range: 400-800 g), $400 \mathrm{~g}$ (range: 350-600 g) and $300 \mathrm{~g}$ (range: 250-400 g) in ponds in Gampaha, Puttalam and Ampara districts respectively. Except three fish farmers in Gampaha and Puttalam districts, who supplied their products to wholesale fish traders, all other fish farmers supplied their 
products to retail traders (bicycle vendors) and to the people living the vicinity of their ponds.

Each bicycle vendor purchased $30-40 \mathrm{~kg}$ of fish at a time. Hence, the harvesting of fish continued for several days. It was observed that some farmers in Gampaha district had a practice of harvesting fish from ponds commencing from the 5th month and larger fish were first harvested using selective fishing gear. Commonly used fishing gear types for harvesting of fish in ponds are gillnets, cast nets, drag nets and hook and line.

Average prices for farmed tilapia prevailed in Gampaha and Puttalam respectively were Rs. 210/kg (range: Rs.200-220/kg) and Rs. 216/kg (range: Rs.200$250 / \mathrm{kg}$ ), while it ranged from Rs. 140 to $180 / \mathrm{kg}$ with an average of Rs.160/kg in Ampara district. (In December 2014, US\$ $1 \approx$ Rs. 130.)

\section{Fish Production and Profitability}

Average fish yield per culture cycle from ponds respectively in Gampaha, Puttalam and Ampara districts were 9,192.0 kg/ha (range from 2,069.0 to 12,519.0 kg/ha), $6074.0 \mathrm{~kg} / \mathrm{ha}$ (range from 2,592.0 to $10,540.0 \mathrm{~kg} / \mathrm{ha}$ ) $3270.0 \mathrm{~kg} / \mathrm{ha}$ (range from $1,600.0$ to $5,555.0 \mathrm{~kg} / \mathrm{ha})$.

Details of costs and returns for $500 \mathrm{~m}^{2}$ ponds in three districts under consideration, computed based on the information on relevant costs and returns collected during the survey is given in Table 1. Computation of economic results showed wide variation for production, costs and profit margin among three districts. Operational costs for $\mathrm{kg}$ of fish produced were Rs. 71.44 (Gampaha), Rs. 56.86 (Puttalam) and Rs. 89.82 (Ampara). Feed accounted for $60.9 \%, 69.0 \%$ and $82.9 \%$ of operational cost for ponds in the above three districts respectively.

Net profit over operational costs per $\mathrm{kg}$ of fish is low in ponds in Ampara (Rs. 70.10), when compared to ponds in Gampaha (Rs. 138.56) and Puttalam (Rs. 159.14). Net profit over both capital and operational cost for a culture cycle in 500 $\mathrm{m}^{2}$ ponds are Rs. 61,447.67 (Gampaha), Rs. 46,097.87 (Puttalam) and Rs. 9,241.67 (Ampara).

\section{Discussion}

Aquaculture is purported to be an age-old practice that commenced in China. However, its significance to the contribution to human food is of only three to four decades old. Of 136.2 million tonnes of total food fish amount available for human consumption in the world, aquaculture produced 66.2 million tonnes of food fish in 2012 (FAO 2014). Asia-Pacific region is the world leader in aquaculture representing more than 89 percent of total global aquaculture fish production in 2012. Freshwater fin fish account for around two-third of farmed food fish produced in Asia and the Pacific.

Freshwater omnivorous and herbivorous fish are an important food for many countries in Asia and the Pacific region. Pond culture still remains the dominant production system for fin fish species and more than 80 percent of the world aquaculture production is from aquaculture ponds (Asia Pacific Fishery Commission 
2014). Although fish farming in ponds is very popular in many Asian countries, Sri Lanka lag far behind in this aspect. Sri Lanka government's initial attempts to introduce small-scale fish farming in ponds during 1980-1985 period was a failure. Fisheries authorities attributed this failure to lack of tradition of fish farming, inadequate transfer of fish farming technology to farmers, weak extension service and non-attractive financial returns from these small pond culture systems due to low output and low price for freshwater fish species prevailed at that time. Since then the second attempt for introduction of food fish farming in ponds was made after around 30 years.

Table 1. Cost and return from Nile tilapia farming in backyard ponds $\left(500 \mathrm{~m}^{2}\right)$ in Gampaha, Puttalam and Ampara districts for a culture cycle.

\begin{tabular}{|c|c|c|c|}
\hline Item & Gampaha & Puttalam & Ampara \\
\hline \multicolumn{4}{|l|}{ Return } \\
\hline Production $(\mathrm{kg})$ & 459.6 & 303.7 & 163.5 \\
\hline Value (Rs.) & $96,516.00^{1}$ & $65,599.20^{2}$ & $26,160.00^{3}$ \\
\hline \multicolumn{4}{|l|}{ Operational costs (Rs.) } \\
\hline Fingerlings & $5,377.00$ & $4,084.00$ & $2,023.00$ \\
\hline Lime/chemicals & - & 256.00 & 480.00 \\
\hline Organic fertilizer & - & 187.00 & - \\
\hline Feeds & $20,010.00$ & $11,920.00$ & $12,182.00$ \\
\hline Hired labour & $3,645.00$ & 403.00 & - \\
\hline Miscellaneous & $3,803.00$ & 418.00 & - \\
\hline Total operational cost (Rs.) & $32,835.00$ & $17,268.00$ & $14,685.00$ \\
\hline Net profit over operational cost (Rs.) & $63,681.00$ & $48,331.00$ & $11,475.00$ \\
\hline Net profit over capital ${ }^{4} \&$ operational costs (Rs.) & $61,447.67$ & $46,097.87$ & $9,241.67$ \\
\hline Operational cost $/ \mathrm{kg}$ of fish (Rs.) & 71.44 & 56.86 & 89.82 \\
\hline Net profit over operational cost $/ \mathrm{kg}$ of fish (Rs.) & 138.56 & 159.14 & 70.18 \\
\hline \multicolumn{4}{|l|}{${ }^{1}$ Avg selling price - Rs. $210 / \mathrm{kg}$} \\
\hline \multicolumn{4}{|l|}{${ }^{2}$ Avg selling price - Rs. $216 / \mathrm{kg}$} \\
\hline \multicolumn{4}{|c|}{${ }^{3}$ Avg selling price - Rs.160/kg } \\
\hline \multicolumn{4}{|c|}{$\begin{array}{l}{ }^{4} \text { Avg cost of construction of a } 500 \mathrm{~m}^{2} \text { pond - Rs 35,000.00; Period of depreciation - } \\
10 \text { yrs; Culture cycle - } 8 \text { month; Depreciated capital cost per culture cycle - Rs. } \\
2,233.33\end{array}$} \\
\hline
\end{tabular}

In ponds constructed under the island-wide multi-sector Divi Neguma programme, fisheries authorities in Sri Lanka recommended farming of Nile tilapia as it fetches at higher prices than carp varieties. In addition, other qualities of Nile tilapia favouring aquaculture such as ability to tolerate (i) crowding, (ii) relatively poor water quality, and (iii) other stress factors together with its less susceptibility to disease are the reasons for recommending Nile tilapia as the suitable species for farming in backyard ponds. Pullin (1984) termed tilapias "aquatic chicken" - an animal that can be farmed easily and economically, and with the same broad market appeal as chicken. In 2012, Asia-Pacific region produced 3.04 million tonnes of Nile tilapia and other varieties of tilapia. Nile tilapia is commonly cultured in backyard 
ponds in Asian region to supplement the income of poor households and to provide fresh source of protein (De Silva et al. 2004).

Fish farmers relied on government fish hatcheries to purchase tilapia fingerlings. Of the state-owned hatcheries, only two hatcheries produce a limited number of sex reversed all-male tilapia fingerlings. Although aquaculture extension officers encouraged farmers to stock all-male tilapia fingerlings in their ponds, all the farmers in Ampara district and very few farmers in other two districts opted for mixed-sex tilapia culture. It was revealed during the discussions with these farmers, that although they are aware of advantages of all-male tilapia culture such as fast growth, they were compelled to use mixed-sex tilapia due to high costs involved in transporting all-male tilapia fingerlings for long distances and the inability of government hatcheries to supply all-male tilapia fingerlings to meet the demand.

Fish production per unit area varied greatly in ponds within the district as well as between districts. Average unit area production observed for ponds respectively in Gampaha and Puttalam districts were $181 \%$ and $85 \%$ higher than that of Ampara district. These differences can be attributed to variation in soil and water quality, fingerlings quality (mixed-sex verses all-male), management practices adapted, input use levels, etc. According to Dey (2001), mean yields recorded for mono-culture of tilapia in ponds were 6.6, 6.3, 3.0 and 1.7 tonnes/ha/yr in Thailand, The Philippines, Vietnam and Bangladesh respectively. Fish yields of 10.1 and 14.9 $\mathrm{mt} / \mathrm{ha} / \mathrm{yr}$ of Nile tilapia have been reported from ponds integrated with poultry in Thailand and Nigeria respectively (Suresh and Bhujel 2012). In general, the following differences in inputs provided by farmers in the three districts were observed. Eighty four pecent of farmers in Gampaha, $66 \%$ of farmers in Puttalam opted for all-male tilapia culture, while all farmers in Ampara practiced mixed-sex culture. Average stocking densities adopted varied considerably between the three districts with Gampaha farmers using highest density $\left(5 / \mathrm{m}^{2}\right)$ followed by Puttalam $\left(2.8 / \mathrm{m}^{2}\right)$ and Ampara $\left(1.7 / \mathrm{m}^{2}\right)$ farmers. Application of cow-dung to fertilize water varied considerably between ponds in three districts with Puttalam farmers using higher rate of fertilizer per culture cycle $\left(0.4 \mathrm{~kg} / \mathrm{m}^{2}\right)$ when compared to ponds in Ampara $(0.11$ $\mathrm{kg} / \mathrm{m}^{2}$ ). In Gampaha district, fish farmers did not apply fertilizer to aquaculture ponds.

Farmers from Gampaha and Puttalam districts appear to be more innovative with regard to feeding of fish. The cultured stocks were fed with kitchen waste, dateexpired bread and shrimp feed, cooked poultry waste and low cost agricultural byproducts such as broken rice and coconut poonac. Further, as Gampaha and Puttalam are major dried fish producing districts, farmers of these two districts took the advantage of availability of considerable quantities of dried fish processing waste (pieces, fish heads, etc.) to feed the fish.

Notable difference in the water quality was observed in respect of majority of ponds in the Gampaha district. Eleven out of 13 ponds covered under the survey in Gampaha district were situated close to inflows (tributaries/streams) of the Negombo lagoon and obtained water supply from these inflows. Slightly saline conditions (0-4 ppt) prevailed in these ponds during certain periods of the year (Pushpalatha et al. unpublished). Silva et al. (2013) reported that salinity of the inflow area of Negombo lagoon varied between 0-6.5 ppt. Lawson and Anetekhai (2011) have shown that Salinities 0-7 ppt were tolerated by hatchery-reared $O$. niloticus 
fingerlings and that the most preferred salinity was $1 \mathrm{ppt}$. Presence of these favourable conditions may have induced fish farmers to adopt fairly high stocking densities.

Majority of fish farmers in Gampaha district carried out selective harvesting to remove bigger fish $(>500 \mathrm{~g})$ from the 5 th month onwards. This practice of removal of bigger fish from ponds may have reduced competition among fish and pave the way for smaller fish to grow faster and attain marketable size early, in turn facilitating higher production from ponds.

It was noted that average size of fish at the time of harvest was the lowest in ponds in Ampara district in spite of adopting low stocking densities. The most important problem in growing tilapia to an acceptable market size is their early and uncontrolled reproduction in culture systems, especially earthen ponds (Suresh and Bhujel 2012). Their early maturation and frequent reproduction direct a significant amount of energy towards gonadal development and reproductive activities, and thereby reduce the energy available for growth. Furthermore, proliferation of juveniles in the culture system increases demand for food and other resources. A proven solution to this problem is stocking of all-male tilapia. Male tilapias grow faster than females and therefore, culture of all-male tilapia results in increased growth, besides prevention of early reproduction.

It is presumed, in addition to differences in water quality and input levels etc., that the extent of use of all-male tilapia for farming would have been a major factor influencing the differences in fish production observed among ponds in three districts. During the discussions with fish farmers, it was observed that in general, fish farmers in Gampaha and Puttalam are with more entrepreneur-attitudes than those in Ampara.

Computation of economic results based on the information collected during the survey shows that tilapia farming in backyards ponds is profitable in all three districts, in spite of vast differences in the profit margins among ponds in the three districts. Two main reasons for low profit margin observed for ponds in Ampara are low fish production in ponds and low selling price for tilapia prevailed in the area.

Sustainability of newly introduced fish farming in backyard ponds depend on its profitability, demand for the produced fish, availability of fish seeds and their quality and continuation of priority given by the government. The following recommendations are made for ensuring sustainability and further expansion of farming of tilapia in ponds.

a. It was revealed that non availability of all-male tilapia fingerlings to meet the demand and high transport costs of fish fingerlings for long distance from two government hatcheries compelled many farmers to stock mixed-sex tilapia fingerlings in their ponds. The governmental patronage is needed to be extended for the establishment of small scale all-male tilapia hatcheries that would be owned and managed by the private sector in areas where demand for all-male tilapia exists.

b. Priority given by the government for pond fish farming needs to be continued.

c. More attention should be paid for the development of pond fish farming in districts of Gampaha, Kalutara, Galle, Matara, Kandy, Kegalle, Ratnapura and Nuwaraeliya, where availability of freshwater fish is low. 
d. In districts such as Ampara where availability of tilapia from capture fisheries in reservoirs, timing of stocking of ponds should be adjusted to target harvesting of ponds during lean fish production period of the reservoirs.

\section{References}

Asia Pacific Fishery Commission 2014. Regional overview of aquaculture trends in the Asia Pacific Region 2014, RAP publication 2014/26, 45p.

Chakrabarty R.D. 1983. Fish production in ponds under the subsidy programme in Sri Lanka Journal of Inland Fisheries (Sri Lanka) 2: 107-111.

De Silva S.S., R.P. Subasinghe, D.M. Bartley \& A. Lowther 2004. Tilapia as an alien aquatics in Asia and the Pacific: Review. FAO Fisheries Technical Paper. No.453. Rome. 2004. 65 p.

Dey M.M. 2001. Tilapia production in South Asia and the far East. 17-27 pp. In: Subasinghe, S. \& T. Singh (eds), Tilapia production, Marketing and Technological Development. INFOFISH, Kuala Lumpur, Malaysia.

FAO 2014. The State of World Fisheries and Aquaculture 2014. FAO, Rome 223 p.

Lawson E.O. \& M.A. Anetekhai 2011. Salinity tolerance and preference of hatchery reared Nile tilapia, Oreochromis niloticus (Linneaus 1758). Asian Journal of Agricultural Sciences 3(2): 104-110.

Pullin R.S.V. 1984. Tilapia-Potentially an international food commodity. INFOFISH Marketing Digest 3: 35-36.

Silva E.I.L., J. Katupotha, O. Amarasinghe, H. Manthrithilake \& R. Ariyaratne 2013. Lagoons of Sri Lanka: from the origins to the present. International Water Management Institute (IWMI), Colombo. $122 \mathrm{p}$.

Suresh V. \& C. Bhujel 2012. Tilapias. 338-364 pp. In: Lucas J.S. \& P.C. Southgate (eds), Aquaculture: Farming Aquatic Animals and Plants. Second Edition. Wiley-Blackwell Publishing, Chichester. 629 p. 